\title{
THE PROPOSED LEGALIZATION OF PROSTITUTION IN SOUTH AFRICA - FRAMING THE DEBATE FROM A LIBERAL PERSPECTIVE
}

\author{
Stephen Peté \\ BA LLB LLM M Phil \\ Associate Professor, Faculty of Law \\ University of KwaZulu-Natal, Durban \\ Attorney of the High Court of South Africa
}

\section{SUMMARY}

The debates surrounding the issue of whether or not prostitution or sex work ought to be legal or illegal have a long and convoluted history, both in South Africa and abroad. This article seeks to provide greater clarity and focus to current debates on this complex issue, in particular from a liberal perspective. By examining certain of the main issues at stake for those committed to the broad tenets of liberal ideology, the article hopes to bring at least some measure of clarity and focus to a contentious set of theoretical and empirical questions. It is argued that, from a liberal perspective, to interfere with the freedom of each South African to make his or her own moral choices is to interfere with the very foundation of South Africa's hard-won constitutional democracy. In order to convince those committed to truly liberal principles of the need for the criminal law to prohibit sex work, it must be shown that it causes either "harm" or "offence" to others. Liberals will accept neither the principle of "legal moralism" nor that of "legal paternalism" as legitimate reasons to criminalize sex work.

\section{$1 \quad$ INTRODUCTION}

In the years leading up to South Africa's hosting of the 2010 FIFA World Cup, there was much debate in the South African mass media on the issue of whether or not prostitution should be legalized, in order to cater for those among the thousands of fans expected to visit the country, who might wish to make use of the services offered by sex workers. ${ }^{1}$ Coincidentally, as debate on this issue raged in the media, the South African Law Reform Commission published a Discussion Paper on the issue of adult prostitution in South Africa, setting out various options as to the way forward, including

The terms "prostitution" and "sex work" (together with their respective derivatives "prostitute" and "sex worker") are used interchangeably in this article. The author is aware that both terms are ideologically and politically loaded. Readers are requested not to pre-judge the ideological positions taken in this article simply from the use of one or the other of the above terms. No slight or offence is intended to readers who may hold strong views on which particular term ought to be used. 
continued total criminalization, partial criminalization, non-criminalization, or regulation. ${ }^{2}$ Furthermore, in what may be regarded as another interesting coincidence, at the same time that South Africans were debating whether or not to legalize prostitution, a similar debate was taking place in Britain, a country with close historical links to South Africa. In the case of the debate in Britain, however, the starting point was the reverse of that in South Africa, since the broad issue to be decided was whether or not prostitution, which is legal in Britain, should be criminalized.

The purpose of this article is not to suggest even a partial "solution" to the debates referred to above. The theoretical and empirical complexities of the issues involved make that too complex a task for an article of this nature. Instead, what this article hopes to achieve, is to make use of certain theoretical perspectives in order to clarify and, perhaps, provide greater focus to certain aspects of the complex debates which inevitably surround this broad issue. In particular, the article sets out to frame the debate from a liberal perspective. In examining certain of the main issues at stake in the debate for those committed to the broad tenets of liberal ideology, the article hopes to bring at least some measure of clarity and focus to a contentious and complex set of theoretical and empirical questions.

At the outset, it is worth pointing briefly to two aspects of the legalization/criminalization debate as it relates to prostitution:

The first aspect is the enduring and apparently cyclical nature of the debate. It has already been pointed out that, while South Africans were (in general terms) debating whether or not to legalize prostitution in preparation for the FIFA World Cup, Britons were (in general terms) debating whether or not prostitution should be criminalized. Taking Britain as an example and focusing only on what the theorists dealt with in this particular article, it is clear that this same debate has been revisited at regular intervals over a period of a century and a half in that country, by some of its finest legal, political and philosophical minds. Despite this, the issue remains as contentious today as it ever was in the past, with opinions divided and no resolution in sight.

The second aspect of the debate that is worth pointing out at this stage is its polarized nature, particularly when it comes to the issue of the harm allegedly caused by prostitution. On the one side, there are those who believe that prostitution is, inherently, a form of violence against women. They argue that, in a patriarchal world characterized by the marginalization and oppression of women, the overwhelming majority of women who supposedly "consent" to become prostitutes lack any real alternatives, which means that their consent is not real but fictional. In terms of this view, men

2 South African Law Reform Commission Project 107 - Discussion Paper on Sexual Offences: Adult Prostitution published in 2009. This Discussion Paper was part of a broader review of the law relating to sexual offences in South Africa, which had started in 1998 and is due to end in 2011. Retaining a policy of total criminalization would mean that all forms of sex work remain illegal and that all parties involved remain liable to criminal prosecution; partial criminalization would target mainly those persons buying the service, as opposed to the sex workers providing the service; non-criminalization would mean the repeal of all laws that criminalize sex work; regulation would mean that, although sex work would not be illegal, it would be regulated by the state. 
who use prostitutes should be regarded as offenders, perhaps even as rapists if the argument is taken to its extreme. On the other side, there are those who believe that the majority of sex workers enter into this particular line of work of their own free will. They argue that the real harm suffered by many sex workers is not because of the nature of work itself, but as a result of the fact that this particular form of work is criminalized. They argue that, were this form of work to be legalized, sex workers would not be so easily exploited, since they would become entitled to the same legal protections as other workers.

The arguments outlined in the previous paragraph by no means exhaust the many-nuanced positions that are adopted by those who take part in this debate. For example, there are those who believe that the debate ought to be centred on the issue of the morality or otherwise of prostitution, as opposed, simply, to the harm allegedly caused by the practice. ${ }^{3}$ Without elaborating on the many alternative arguments raised, it is probably fair to say that the prospects for a reconciliation between those who (broadly) support the legalization of prostitution, and those who (broadly) oppose this position, appear remote. From the point of view of this article, the interesting question is why this should, of necessity, be the case. In particular, why is it not possible for those who argue in favour of the legalization of prostitution to compromise their position somewhat? Why insist that the criminal law not interfere in any way with a form of work which many believe constitutes a form of institutional violence against women? Should the criminal law not be allowed to err on the side of caution by, at least, targeting and punishing those (mainly male) "clients" who keep this (dangerous and destructive?) "industry" in business, by purchasing the services of (mainly female) sex workers? Should the desire of (some) men to make use of the services of prostitutes and the willingness of some women to provide such services (which "willingness" may be the result of a lack of suitable alternative options), be allowed to prevent the criminal law from protecting society in general or women in particular, including the prostitutes themselves?

The view that the "individual choices" of those who wish to participate in sex work, either as clients or sex workers, cannot really stack up against real concerns that people, in particular women, are exposed to harm by this practice, is well expressed in the following snippet which appeared in one of the daily South African newspapers, in the run up to the FIFA World Cup:

"[Western Cape Premier Helen Zille] said sex work could not be separated from human trafficking. 'It's not just an issue of being liberal around people's individual choice, because most often the women and children involved have no choice,' she said."

3 If it is true that prostitution is the world's oldest profession, it is also true that it is a profession which has, over the ages, been mired in moral controversy. Eg, even the most cursory search of the internet using the keywords "prostitution" and "Bible" will reveal a myriad websites adopting fiercely conflicting positions on the morality/immorality of prostitution. Further, it is interesting to note that, as a subsense of the noun "prostitution", the Oxford Dictionary of English describes this practice as being "the unworthy or corrupt use of one's talents for personal or financial gain". See the Oxford Dictionary of English, Second Edition, 2003, Oxford University Press: Oxford.

4 The Mercury 2 March 20104. 
The above quotation makes clear the link between adopting a "liberal" ideological position and a concern for "people's individual choice". But what is it, from a liberal perspective, which makes the issue of individual choice so important? At the heart of liberal thinking lies the imperative to protect the freedom of the individual. This central pillar of liberal thought demands that each individual be surrounded by an inviolate sphere of personal moral freedom, which is outside the influence or reach of the moral majority. For liberal thinkers, what is (to a significant extent) at stake in the debate around the legalization or criminalization of prostitution, is the liberal commitment to individual autonomy. The freedom of individuals to decide upon and pursue their own conception of the good is sacrosanct to liberal thinkers. To make use of the coercive power of the criminal law to stamp out or suppress prostitution is, potentially, to risk interfering with the freedom of each individual in society to make his or her own moral choices. Furthermore, the liberal commitment to individual autonomy goes to the very heart of the liberal conception of what is meant by the term "constitutional democracy". To interfere with the freedom of each South African to make his or her own moral choices is, therefore, to interfere with the very foundation of South Africa's hard won constitutional democracy.

With the above as a general introduction, we are now ready to begin with the "framing" of the prostitution debate from a liberal perspective.

\section{THE ROOTS OF LIBERAL THINKING - JOHN STUART MILL}

John Stuart Mill's essay "On Liberty", which was published in 1859, is a foundational document within the liberal philosophical and political tradition. In this essay, Mill sets out to explore the nature and limits of the power which may legitimately be exercised by society over the individual. ${ }^{5}$ This question is fundamental to those who fall within the broad liberal tradition. The liberal tradition is centrally concerned with defining and protecting the right of each individual in a democratic society to define his or her own conception of what constitutes a good life, and to live his or her life accordingly, without undue interference. It is very important to liberal thinkers that this individual freedom, the space for individuals to decide upon and live out their own particular conceptions of the good, be jealously guarded against inroads due to societal pressures. Towards the beginning of his essay, Mill points to the danger inherent in democratic societies, of the possible abuse of power by the majority in a particular society. For whatever reason, such a majority "may desire to oppress a part of their number" and Mill argues that "precautions are as much needed against this, as against any other abuse of power". ${ }^{6}$ He points out that "the tyranny of the majority' is now generally included among the evils against which society requires to be on its guard". But it is not simply overt political tyranny which Mill sees as a potential danger within democratic societies, but also what he calls "social tyranny" (perhaps we could characterize this as the tyranny of the accepted mores of

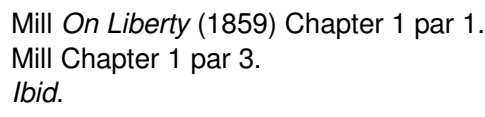


the majority), which he regards as a potentially more dangerous and insidious problem:

"Society can and does execute its own mandates: and if it issues wrong mandates instead of right, or any mandates at all in things with which it ought not to meddle, it practises a social tyranny more formidable than many kinds of political oppression, since, though not usually upheld by such extreme penalties, it leaves fewer means of escape, penetrating much more deeply into the details of life, and enslaving the soul itself. Protection, therefore, against the tyranny of the magistrate is not enough; there needs protection also against the tyranny of the prevailing opinion and feeling; against the tendency of society to impose, by other means than civil penalties, its own ideas and practices as rules of conduct on those who dissent from them; to fetter the development, and, if possible, prevent the formation, of any individuality not in harmony with its ways, and compel all characters to fashion themselves upon the model of its own."

Mill pleads for there to be "a limit to the legitimate interference of collective opinion with individual independence", and argues that finding that limit and maintaining it against encroachment "is as indispensable to a good condition of human affairs, as protection against political despotism". "He suggests that a "simple principle" be used when deciding whether or not society may legitimately exercise compulsion and control over an individual, whether such compulsion and control is in the form of physical force sanctioned by legal penalties or what he calls the "moral coercion of public opinion". ${ }^{10} \mathrm{He}$ set out this "simple principle" as follows:

"[T]he sole end for which mankind are warranted, individually or collectively in interfering with the liberty of action of any of their number, is self-protection ... [T]he only purpose for which power can be rightfully exercised over any member of a civilized community, against his will, is to prevent harm to others. His own good, either physical or moral, is not a sufficient warrant. He cannot rightfully be compelled to do or forbear because it will be better for him to do so, because it will make him happier, because, in the opinions of others, to do so would be wise, or even right. These are good reasons for remonstrating with him, or reasoning with him, or persuading him, or entreating him, but not for compelling him, or visiting him with any evil, in case he do otherwise. To justify that, the conduct from which it is desired to deter him must be calculated to produce evil to some one else. The only part of the conduct of any one, for which he is amenable to society, is that which concerns others. In the part which merely concerns himself, his independence is, of right, absolute. Over himself, over his own body and mind, the individual is sovereign.

In the years following its publication in Mill's essay, the "simple principle" set out above, which has come to be referred to as Mill's "harm principle", has exercised and continues to exercise a profound influence upon liberal thought in particular. As will be discussed below, over many years the "harm principle" has been central to debates on the issue of the legalization/criminalization of prostitution. For the moment, it is worth noting the radical nature and far-reaching implications of the principle as elucidated

\footnotetext{
Mill Chapter 1 par 4.

Ibid.

Mill Chapter 1 par 9.

Ibid.
} 
by Mill. $^{12}$ For Mill, it is clearly more important to allow an individual the freedom to make his or her own decisions about how to live his or her life, than it is to protect individuals from the consequences of their decisions freely made. Paternalism, protecting individuals from themselves, does not play a part in Mill's harm principle, although he does make it quite clear that the principle "is meant to apply only to human beings in the maturity of their faculties" and that he is "not speaking of children, or of young persons below the age which the law may fix as that of manhood or womanhood". ${ }^{13}$

But why is Mill so intent on upholding the value of individual human freedom, even if it means allowing individuals to suffer the consequences of patently unwise decisions? Should those committed to democracy not strive for a caring society, which intervenes to assist those individuals who embark on a self-destructive path, even if it does mean restricting their individual freedom to some extent? The answer lies, perhaps, in Mill's belief that it is not for society to decide what is good for us, but for each of us to decide what is good for ourselves:

"The only freedom which deserves the name, is that of pursuing our own good in our own way, so long as we do not attempt to deprive others of theirs, or impede their efforts to obtain it. Each is the proper guardian of his own health, whether bodily, or mental or spiritual. Mankind are greater gainers by suffering each other to live as seems good to themselves, than by compelling each to live as seems good to the rest."

Following Mill's line of argument, we ought to be deeply sceptical of the idea that the majority in any particular society, even a constitutional democracy, knows what is best for each and every member of that society. Allowing each individual the freedom to form his or her own opinions, and then to act in accordance with those opinions (provided, of course, that such conduct does not harm the interests of others), is vitally important for a range of important reasons:

"That mankind are not infallible; that their truths, for the most part, are only halftruths; that unity of opinion, unless resulting from the fullest and freest comparison of opposite opinions, is not desirable, and diversity not an evil, but a good, until mankind are much more capable than at present of recognizing all sides of the truth, are principles applicable to men's modes of action, not less

12 Mill clearly regards individual human freedom as being of paramount importance. This is clear from his delineation of the appropriate scope and extent of human liberty as follows: "It comprises, first, the inward domain of consciousness; demanding liberty of conscience, in the most comprehensive sense; liberty of thought and feeling; absolute freedom of opinion and sentiment on all subjects, practical or speculative, scientific, moral, or theological. The liberty of expressing and publishing opinions may seem to fall under a different principle, since it belongs to that part of the conduct of an individual which concerns other people; but, being almost of as much importance as the liberty of thought itself, and resting in great part on the same reasons, is practically inseparable from it. Secondly, the principle requires liberty of tastes and pursuits; of framing the plan of our life to suit our own character; of doing as we like, subject to such consequences as may follow; without impediment from our fellow-creatures, so long as what we do does not harm them even though they should think our conduct foolish, perverse, or wrong. Thirdly, from this liberty of each individual, follows the liberty, within the same limits, of combination among individuals; freedom to unite, for any purpose not involving harm to others: the persons combining being supposed to be of full age, and not forced or deceived." See Chapter 1 par 12.

13 Mill Chapter 1 par 10.

14 Mill Chapter 1, par 13. 
than to their opinions. As it is useful that while mankind are imperfect there should be different opinions, so is it that there should be different experiments of living; that free scope should be given to varieties of character, short of injury to others; and that the worth of different modes of life should be proved practically, when any one thinks fit to try them. It is desirable, in short, that in
things which do not primarily concern others, individuality should assert itself."

It is clear, therefore, that Mill places the highest value on preserving and protecting individuality. He bemoans the fact that the intrinsic worth of "individual spontaneity" is not usually recognized by the majority in society, since: "The majority, being satisfied with the ways of mankind as they now are (for it is they who make them what they are), cannot comprehend why those ways should not be good enough for everybody; and what is more, spontaneity forms no part of the ideal of the majority of moral and social reformers, but is rather looked on with jealousy, as a troublesome and perhaps rebellious obstruction to the general acceptance of what these reformers, in their own judgment, think would be best for mankind."16 Even in democratic societies, therefore, individuals who think and act differently to those who form part of the "moral majority", may be subjected to hostile treatment from society as a whole, even though their chosen way of living may pose no direct threat to society. In fact, it is not in the interests of society to suppress the individuality of its members. If the individuality of each member of a particular society is protected and nurtured, Mill believes that the whole society benefits: "It is not by wearing down into uniformity all that is individual in themselves, but by cultivating it and calling it forth, within the limits imposed by the rights and interests of others, that human beings become a noble and beautiful object of contemplation; and as the works partake the character of those who do them, by the same process human life also becomes rich, diversified, and animating, furnishing more abundant aliment to high thoughts and elevating feelings, and strengthening the tie which binds every individual to the race, by making the race infinitely better worth belonging to." 17 Mill believes that it is only when the conduct of an individual negatively affects the interests of others that society is justified in prohibiting such conduct. ${ }^{18}$ When this is not the case, such conduct should not be prohibited, even though the majority in society may strongly disapprove of the individual and the conduct concerned for moral reasons. The individual must be allowed to bear the natural consequences of his or her conduct, without further punishment from society:

"If he displeases us, we may express our distaste, and we may stand aloof from a person as well as from a thing that displeases us; but we shall not therefore feel called on to make his life uncomfortable. We shall reflect that he already bears, or will bear, the whole penalty of his error; if he spoils his life by mismanagement, we shall not, for that reason, desire to spoil it still further: instead of wishing to punish him, we shall rather endeavor to alleviate his punishment, by showing him how he may avoid or cure the evils his conduct tends to bring upon him. He may be to us an object of pity, perhaps of dislike, but not of anger or resentment; we shall not treat him like an enemy of society:

\footnotetext{
Mill Chapter 3 par 1.

Mill Chapter 3 par 2.

Mill Chapter 3 par 9

Mill Chapter 4 par 3.
} 
the worst we shall think ourselves justified in doing is leaving him to himself

Therefore it would seem that, for Mill, together with individual freedom to shape one's life in any way one sees fit (provided that one's way of life does not prejudicially affect the interests of others), comes the personal responsibility to live with the natural consequences of the path one has chosen. For Mill, respect for a person's individuality, seems to include respecting that person's right to make what most would regard as poor life choices, and allowing that person to live with the consequences of those choices. Mill is alive to the possible objection to his argument that it is impossible for an individual to make poor life choices without harming anyone else since, as the saying goes, no man is an island unto himself. ${ }^{20}$ Mill insists, however, that it is only the harmful conduct itself which may be prohibited, and not the particular lifestyle choices of the individual concerned, even though the moral majority may believe that these choices are ultimately to blame for the harmful conduct. ${ }^{21}$ As to the potential harm which society may suffer by allowing individuals to continue with what society regards as self-destructive lifestyles, Mill states that "with regard to the merely contingent or, as it may be called, constructive injury which a person causes to society, by conduct which neither violates any specific duty to the public, nor occasions perceptible hurt to any assignable individual except himself; the inconvenience is one which society can afford to bear,

19 Mill Chapter 4 par 7.

20 Mill articulates this possible objection as follows: "The distinction here pointed out between the part of a person's life which concerns only himself, and that which concerns others, many persons will refuse to admit. How (it may be asked) can any part of the conduct of a member of society be a matter of indifference to the other members? No person is an entirely isolated being; it is impossible for a person to do anything seriously or permanently hurtful to himself, without mischief reaching at least to his near connections, and often far beyond them. If he injures his property, he does harm to those who directly or indirectly derived support from it, and usually diminishes, by a greater or less amount, the general resources of the community. If he deteriorates his bodily or mental faculties, he not only brings evil upon all who depended on him for any portion of their happiness, but disqualifies himself for rendering the services which he owes to his fellow-creatures generally; perhaps becomes a burden on their affection or benevolence; and if such conduct were very frequent, hardly any offence that is committed would detract more from the general sum of good. Finally, if by his vices or follies a person does no direct harm to others, he is nevertheless (it may be said) injurious by his example; and ought to be compelled to control himself, for the sake of those whom the sight or knowledge of his conduct might corrupt or mislead." See Mill Chapter 4 par 8.

21 Mill makes this argument, inter alia, as follows: "If, for example, a man, through intemperance or extravagance, becomes unable to pay his debts, or, having undertaken the moral responsibility of a family, becomes from the same cause incapable of supporting or educating them, he is deservedly reprobated, and might be justly punished; but it is for the breach of duty to his family or creditors, not for the extravagance ... Whoever fails in the consideration generally due to the interests and feelings of others, not being compelled by some more imperative duty, or justified by allowable self-preference, is a subject of moral disapprobation for that failure, but not for the cause of it, nor for the errors, merely personal to himself, which may have remotely led to it. In like manner, when a person disables himself, by conduct purely self-regarding, from the performance of some definite duty incumbent on him to the public, he is guilty of a social offence. No person ought to be punished simply for being drunk; but a soldier or a policeman should be punished for being drunk on duty. Whenever, in short, there is a definite damage, or a definite risk of damage, either to an individual or to the public, the case is taken out of the province of liberty, and placed in that of morality or law." See Mill Chapter 4 par 10. 
for the sake of the greater good of human freedom..22 In other words, we may believe for whatever reason that our neighbour's lifestyle is disgusting and immoral, and the knowledge that he has chosen this lifestyle may bother us greatly. As long as he is not causing actual harm to the community or to any other individual, however, if we value individual human freedom, we simply have to put up with the fact that he has chosen to live differently to us, even if our view is supported by the overwhelming majority in our community. ${ }^{23}$

Once we have reached this point in the argument, another important issue comes to the fore. It may be all very well, out of respect for human freedom, not to prohibit another person from making what we consider to be immoral and unwise life choices, but what if that person sets out to convince other members of our society to follow his lead? Are we entitled to prohibit that person from soliciting others to follow his way of thinking or living? Mill answers this question firmly in the negative, stating that: "If people must be allowed, in whatever concerns only themselves, to act as seems best to themselves at their own peril, they must equally be free to consult with one another about what is fit to be so done; to exchange opinions, and give and receive suggestions."24 $\mathrm{He}$ is not so sure of the answer, however, in those situations in which the person doing the soliciting derives financial gain out of converting others to his way of thinking or living, and describes the quandary as follows:

"The question is doubtful, only when the instigator derives a personal benefit from his advice; when he makes it his occupation, for subsistence, or pecuniary gain, to promote what society and the State consider to be an evil. Then, indeed, a new element of complication is introduced; namely, the existence of classes of persons with an interest opposed to what is considered as the public

22 Mill Chapter 4 par 11.

23 Not everyone would agree with Mill on this point. Eg, the great twentieth century jurisprudential philosopher Herbert Hart (whose views are examined in greater detail in the sections which follow) seems prepared to acknowledge that the law may, perhaps, be used to outlaw conduct which causes offence to the feelings of others, provided that such offence is "both serious and likely". One would have to weigh up "the seriousness of the offence to feelings" if the conduct is allowed to continue, against "the sacrifice of freedom and suffering" if the conduct is prohibited by law. See Hart Law, Liberty and Morality (1968 [1963]) 43. Hart points out that it is important to distinguish those situations in which the pubic are openly confronted by what they regard as grossly immoral conduct, from those in which the conduct in question is hidden from public view. While it may be acceptable for the law to intervene in the case of the former (ie, it may be acceptable for the law to intervene in order to protect public decency), it is not acceptable in the case of the latter (ie, the mere knowledge that certain members of society are engaging in conduct which the majority regard as grossly immoral, cannot be regarded as an attack on public decency). Hart refers with approval to the English law at the time relating to prostitution, which took this distinction into account: "It has not made prostitution a crime but punishes its public manifestation in order to protect the ordinary citizen, who is an unwilling witness of it in the streets, from something offensive." See Hart 45. Hart points out that if the law were to prohibit conduct simply because the thought of this conduct taking place caused distress to certain members of society, it would render the value of individual liberty quite nugatory: "Recognition of individual liberty as a value involves, as a minimum, acceptance of the principle that the individual may do what he wants, even if others are distressed when they learn what it is that he does - unless, of course, there are other good grounds for forbidding it. No social order which accords to individual liberty any value could also accord the right to be protected from distress thus occasioned." See Hart 47.

24 Mill Chapter 5 par 8. 
weal, and whose mode of living is grounded on the counteraction of it. Ought this to be interfered with, or not? Fornication, for example, must be tolerated, and so must gambling; but should a person be free to be a pimp, or to keep a gambling-house?"

Mill points out that there are valid arguments to be made for and against the prohibition of soliciting in such situations. On the one hand, if society resolves to uphold individual human freedom by allowing individuals to engage in conduct of which society disapproves and which may be harmful to the individuals concerned (but is not harmful to anyone else), and if part of that freedom is the freedom to speak to others and to suggest that they may wish to engage in such conduct themselves, why should the situation change in any way simply because the individual doing the suggesting makes a living out of the conduct concerned ${ }^{26}$ On the other hand, simply because society may be prepared to allow individuals to engage in the conduct described and to speak to others about trying it for themselves, is it not a bridge too far to expect society to take the extra step of allowing those who have a financial interest in the conduct concerned (who therefore may be expected to have strong ulterior motives) to solicit others to engage in such conduct? ${ }^{27}$ Mill does not provide a definitive answer one way or the other, but does point to a "moral anomaly" which may arise if society decides to allow certain conduct which it regards as morally reprehensible, but to prohibit those with a financial interest from soliciting others to take part in such conduct:

"There is considerable force in these arguments [i.e. arguments in favour of the prohibition of soliciting by those with a financial interest]. I will not venture to decide whether they are sufficient to justify the moral anomaly of punishing the accessary, when the principal is (and must be) allowed to go free; of fining or imprisoning the procurer, but not the fornicator, the gambling-house keeper, but not the gambler.

Mill's thinking has continued to influence the debate on the legalization/criminalization of prostitution during the twentieth and early part

25 Ibid.

26 Mill makes this point as follows: "On the side of toleration it may be said, that the fact of following anything as an occupation, and living or profiting by the practice of it, cannot make that criminal which would otherwise be admissible; that the act should either be consistently permitted or consistently prohibited; that if the principles which we have hitherto defended are true, society has no business, as society, to decide anything to be wrong which concerns only the individual; that it cannot go beyond dissuasion, and that one person should be as free to persuade, as another to dissuade." See Mill Chapter 5 par 8.

27 Mill makes this point as follows: "[I]t may be contended, that although the public, or the State, are not warranted in authoritatively deciding, for purposes of repression or punishment, that such or such conduct affecting only the interests of the individual is good or bad, they are fully justified in assuming, if they regard it as bad, that its being so or not is at least a disputable question: That, this being supposed, they cannot be acting wrongly in endeavoring to exclude the influence of solicitations which are not disinterested, of instigators who cannot possibly be impartial - who have a direct personal interest on one side, and that side the one which the State believes to be wrong, and who confessedly promote it for personal objects only. There can surely, it may be urged, be nothing lost, no sacrifice of good, by so ordering matters that persons shall make their election, either wisely or foolishly, on their own prompting, as free as possible from the arts of persons who stimulate their inclinations for interested purposes of their own." See Mill Chapter 5 par 8.

28 Mill Chapter 5 par 8. 
of the twenty-first centuries. Certain of these developments, in the form of the Hart versus Devlin, debate which took place during the late 1950s and early 1960s in Britain, will be examined in the section which follows.

\section{TWENTIETH CENTURY DEVELOPMENTS - THE HART VS DEVLIN DEBATE}

The Hart versus Devlin debate took place between the eminent jurisprudential philosopher, Herbert Hart, on the one hand, and a prominent member of the British House of Lords, Patrick Devlin, on the other. It arose out of the findings of an English Parliamentary Committee of Enquiry, which was appointed in 1954 under the chairmanship of Sir John Wolfenden, to investigate the state of the criminal law in relation to homosexuality and prostitution. The "Committee on Homosexual Offences and Prostitution", which became known as the "Wolfenden Committee", delivered its report in 1957. ${ }^{29}$ The committee was strongly influenced by the arguments put forward by John Stuart Mill discussed in the previous section and concluded, inter alia, that "[u]nless a deliberate attempt is to be made by society, acting through the agency of the law, to equate the sphere of crime with that of sin, there must remain a realm of private morality and immorality which is, in brief and crude terms, not the law's business". ${ }^{30}$ In relation to homosexuality, the committee recommended that homosexual practices between consenting adults in private should no longer be a crime, and in relation to prostitution it recommended that, although prostitution itself should not be made illegal, legislation was needed "to drive it off the streets". During the decade which followed, these recommendations resulted in legislation being passed on each of the two issues concerned. In 1959 the Street Offences Act was passed, which outlawed soliciting in public for purposes of prostitution, although prostitution in itself remained legal. In 1967 the Sexual Offences Act was passed, in terms of which homosexual acts in private were decriminalized.

Devlin did not agree with the philosophical principles on which the Wolfenden Committee had based its findings. In 1959, in a lecture to the British Academy entitled "The Enforcement of Morals", which was subsequently published in 1965, Devlin set out to refute Mill's "harm principle". He maintained that society was not a physical entity, but was in fact a "community of ideas". ${ }^{31}$ He believed that the common morality shared by those in a particular society, their shared ideas about good and evil, served as a form of social cement which held society together. ${ }^{32}$ Since a common morality was essential to the existence of society, it followed that society was entitled to defend itself against a threat to its common morality, in the same way that it was entitled to defend itself against treason:

\footnotetext{
Report of the Committee on Homosexual Offences and Prostitution (CMD 247) 1957.

Quoted in Harris Legal Philosophies (1993) 118-119.

Devlin The Enforcement of Morals (1965) 10-13.

32 According to Devlin: "[S]ociety is not something which is kept together physically; it is held by the invisible bonds of common thought. If the bonds were too far relaxed the members would drift apart. A common morality is part of the bondage. The bondage is part of the price of society; and mankind, which needs society, must pay its price ..." See Devlin 10-13.
} 
"[S]ociety is justified in taking the same steps to preserve its moral code as it does to preserve its government and other essential institutions. The suppression of vice is as much the law's business as the suppression of subversive activities; it is no more possible to define a sphere of private morality than it is to define one of private subversive activity ... There are no theoretical limits to the power of the State to legislate against treason and sedition, and likewise I think there can be no theoretical limits to legislation against immorality."

Clearly, Devlin's argument in this respect is in direct opposition to the "harm principle" put forward by Mill. To Devlin, there is no such thing as private morality which is sacrosanct to each individual in society and which is strictly off limits to state interference as long as it does not cause direct harm. Devlin's argument that the common morality of society is a form of "social cement", means that the state is justified in using the mechanism of law to act as a moral policeman. As to the source of the common morality in which he places so much store, Devlin believes that it is to be found in the views of the proverbial "reasonable man" - that is, the views of the majority of "right-minded" citizens in a particular society:

"How is the law-maker to ascertain the moral judgments of society? ... It is that of the reasonable man. He is not to be confused with the rational man. He is not expected to reason about anything and his judgment may largely be a matter of feeling. It is the viewpoint of the man in the street ... the man in the Clapham omnibus. He might also be called the right-minded man. For my purpose I should like to call him the man in the jury box, for the moral judgment of society must be something about which any twelve men or women drawn at random might after discussion be expected to be unanimous."

Devlin is clearly not as concerned as Mill that individual freedom will be curtailed through the legal imposition of the views of the moral majority on the whole society. ${ }^{35}$ For Devlin, if the majority in society believe that certain conduct (for example prostitution?) is grossly immoral, then the law has every right to prohibit that conduct. But are the arguments that he uses to reach this point sound? Is he correct in his view that the shared morality of society is a form of "social cement" and that we should look to the "man in the Clapham omnibus" to establish the content of this common morality?

The eminent jurisprudential philosopher, Herbert Hart delivered a convincing refutation of Devlin's arguments in his work "Law, Liberty and Morality" which was first published in 1963. Hart points out that there are two broad types of argument that may be advanced in favour of the legal enforcement of morality, which he terms the "moderate" and the "extreme" thesis respectively. Devlin's "social cement" argument is an example of the former type, and Hart's objections to this argument will be discussed shortly. Before we proceed with that discussion, however, it is important to note what

Devlin 10-13.

34 Devlin 15.

35 To be fair to Devlin, he is alive to the danger that minorities may be subjected to persecution by the moral majority if the arguments which he puts forward are taken to the extreme. To prevent this he stipulates that "[n]othing should be punished by the law that does not lie beyond the limits of tolerance" and specifies three principles to prevent the unnecessary criminalization of immoral conduct: 1 . law makers must strive for the maximum freedom that is consistent with social integrity; 2 . law must be slow to change its moral stance; and 3 . as far as possible privacy must be respected. See Devlin 17. 
Hart understands by the term "extreme thesis" and to discuss whether or not arguments of this nature should hold water in South Africa today. Hart describes the "extreme thesis" as follows:

"[T]he extreme thesis does not look upon a shared morality as of merely instrumental value analogous to ordered government, and it does not justify the punishment of immorality as a step taken, like the punishment of treason, to preserve society from dissolution or collapse. Instead, the enforcement of morality is regarded as a thing of value, even if immoral acts harm no one directly, or indirectly by weakening the moral cement of society."

In the present day, it is submitted that arguments of this type might hold water in the context of states which are based upon fundamentalist religious principles. If the law in states of this kind is used to enforce the provisions of a particular form of religious morality, it may be justified on the basis that the enforcement of the moral values concerned is good in itself, and does not require further justification. In other words, it may be argued that the law is enforcing the will of God, and that this is the end of the matter. Clearly, it is difficult to argue with those who adopt such a position, since it comes down to a question of fundamental belief, and in the end one may be forced to agree to disagree. What may fruitfully be discussed, however, is the question of whether or not such arguments (that is, those falling within the category which Hart refers to as the "extreme thesis") are appropriate in the context of post-apartheid South Africa. In this regard, it is submitted that such arguments are not appropriate, for the simple reason that South Africa is not characterized by a homogenous univalent morality, derived from a single source, religious or otherwise. In fact, the very opposite seems to be true, with the post-apartheid South African state being based upon the ideas of unity in diversity, and the tolerance of difference. ${ }^{37}$ It is submitted, therefore, that those who seek to justify the continued criminalization of prostitution in South Africa today, cannot do so by relying on the "extreme thesis", that is, arguments which take it for granted that prostitution is evil in terms of a certain - usually religious - conception of morality, and that it is the purpose of law to uphold that particular moral system.

But what of arguments which fall into the category of what Hart terms the "moderate thesis", of which Devlin's "social cement" argument is one example? These are arguments which do not seek to justify the legal enforcement of morality as good in itself, but instead claim that it is necessary for other important reasons, for example, to ensure social cohesion. In response to Devlin's "social cement" argument - that is, that the common morality of society is the social cement which keeps society together - Hart points out that Devlin produces no convincing empirical evidence to support his contention that deviation from the accepted sexual morality jeopardizes or weakens a society. Hart states that:

"no evidence is produced to show that deviation from accepted sexual morality, even by adults in private, is something which, like treason, threatens the

36 Hart 49.

37 One need look no further than the Preamble of the South African Constitution which states, inter alia, as follows: "We, the people of South Africa ... Believe that South Africa belongs to all who live in it, united in our diversity ..." Preamble of the Constitution of the Republic of South Africa Act 108 of 1996. 
existence of society. No reputable historian has maintained this thesis, and there is indeed much evidence against it ... It is of course clear (and one of the oldest insights of political theory) that society could not exist without a morality which mirrored and supplemented the law's proscription of conduct injurious to others. But there is again no evidence to support, and much to refute, the theory that those who deviate from conventional sexual morality are in other ways hostile to society."

One has only to read the case of Minister of Home Affairs $v$ Fourie (hereinafter "the Fourie case"), which led to the legalization of gay marriages in South Africa, to deduce that the Justices of South Africa's Constitutional Court agree with the argument advanced by Hart in the above quotation. It is worth quoting the words of Justice Sachs in the Fourie case at some length, in order to illustrate why the "social cement" argument advanced by Devlin is not appropriate in the context of post apartheid South Africa:

\begin{abstract}
"A democratic, universalistic, caring and aspirationally egalitarian society embraces everyone and accepts people for who they are. To penalize people for being who and what they are is profoundly disrespectful of the human personality and violatory of equality. Equality means equal concern and respect across difference. It does not presuppose the elimination or suppression of difference. Respect for human rights requires the affirmation of self, not the denial of self. Equality therefore does not imply a levelling or homogenization of behaviour or extolling one form as supreme, and another as inferior, but an acknowledgement and acceptance of difference. At the very least, it affirms that difference should not be the basis for exclusion, marginalization and stigma. At best, it celebrates the vitality that difference brings to any society. The issue goes well beyond assumptions of heterosexual exclusivity, a source of contention in the present case. The acknowledgement and acceptance of difference is particularly important in our country where for centuries group membership based on supposed biological characteristics such as skin colour has been the express basis of advantage and disadvantage. South Africans come in all shapes and sizes. The development of an active rather than a purely formal sense of enjoying a common citizenship depends on recognizing and accepting people with all their differences, as they are. The Constitution thus acknowledges the variability of human beings (genetic and socio-cultural), affirms the right to be different, and celebrates the diversity of the nation. Accordingly, what is at stake is not simply a question of removing an injustice experienced by a particular section of the community. At issue is a need to affirm the very character of our society as one based on tolerance and mutual respect. The test of tolerance is not how one finds space for people with whom, and practices with which, one feels comfortable, but how one accommodates the expression of what is discomfiting.
\end{abstract}

Having dealt with Devlin's "social cement" argument, let us now turn to his "man on the Clapham omnibus" argument. An important starting point in a critique of the latter argument, is to note a crucial distinction made by Hart between "positive morality" on the one hand, and "critical morality" on the other. The former term is taken to mean "the morality actually accepted and shared by a given social group", whereas the latter term connotes "the general moral principles used in the criticism of actual social institutions including positive morality." 40 But why is it necessary to posit a separate "critical morality", which stands apart from the "positive morality" of society? After all, if one is committed to democracy, and if positive morality reflects

38 Hart 50-51.

39 Fourie case par 60.

40 Hart 20. 
the actual views of the majority in society, why is it necessary to take any other form of morality into account? The answer lies, perhaps, in the manner in which one understands the true nature of a democracy. Is democracy a system which simply reflects the will of the majority? Further, is it possible for one to resist the will of the majority in certain instances and still be a democrat? Hart sets out his view on this vital issue as follows:

"It seems fatally easy to believe that loyalty to democratic principles entails acceptance of what may be termed moral populism: the view that the majority have the moral right to dictate how all shall live. This is a misunderstanding of democracy which still menaces individual liberty ... The central mistake is the failure to distinguish the acceptable principle that political power is best entrusted to the majority from the unacceptable claim that what the majority do with that power is beyond criticism and must never be resisted. No one can be a democrat who does not accept the first of these, but no democrat need accept the second. Mill and many others have combined a belief in a democracy as the best - or least harmful - form of rule with the passionate conviction that there are many things which not even a democratic government may do. This combination of attitudes makes good sense, because, though a democrat is committed to the belief that democracy is better than other forms of government, he is not committed to the belief that it is perfect or infallible or never to be resisted."

If one adopts the view of democracy set out in the above quotation (as accepted by Mill, Hart and many other liberal thinkers), it makes sense to posit a separate "critical morality", which stands apart from the "positive morality" of society. Furthermore, it is no surprise that the injunctions of "critical morality" do not always comport with those of "positive morality". Another way of making this point may be to state that the deepest common values of society do not always comport with the views of the moral majority at a particular time. It is not that the values of a few trump the values of the majority, but that the deepest underlying values of the society as a whole, trump the shifting values of the moral majority in that society. Within this conception of democracy, Devlin's "man on the Clapham omnibus" argument is clearly not adequate, since it is concerned only with the shifting values of the moral majority (that is, with "positive morality"). ${ }^{42}$ It does not take into account that, as a matter of critical morality, it is not acceptable simply to impose the views of the moral majority upon the entire community, particularly in cases where those involved in a particular activity are consenting adults, and the conduct concerned does not cause direct harm to anyone other than those persons themselves.

When dealing with an activity such as prostitution which, generally speaking and for the sake of argument, the majority in a culturally conservative country such as South Africa may find morally repugnant, it is particularly important from a liberal perspective that legislators and judges

41 Hart 79-80.

42 The eminent jurisprudential philosopher, Ronald Dworkin, makes this point. In the words of Stephen Guest: "Dworkin's chief point is that a community consensus on morality runs deeper than a surface description of what people in fact, at a certain time and in a certain mood, think or feel ... Dworkin is not opposed to the idea that the community's morality should count. 'What is shocking and wrong' about Lord Devlin's thesis, says Dworkin, 'is not his idea that the community's morality counts, but his idea of what counts as the community's morality'." See Guest Ronald Dworkin 2ed (1997) 112. 
not be swayed unduly by the views of the moral majority, but focus instead on whether or not the activity causes harm. The South African Constitutional Court has, of course, dealt directly with the issue of prostitution in the important case of $S v$ Jordan. ${ }^{43}$ In its judgment, the court makes it clear that it is aware of the danger referred to, and draws an important distinction between "popular conceptions of morality" and "constitutionally articulated values" which is, presumably, similar to the distinction between "positive" and "critical" morality discussed earlier:

\begin{abstract}
"All open and democratic societies are confronted with the need to determine the scope for pluralist tolerance of unpopular forms of behaviour. To posit a pluralist constitutional democracy that is tolerant of different forms of conduct is not, however, to presuppose one without morality or without a point of view. A pluralist constitutional democracy does not banish concepts of right and wrong, nor envisage a world without good and evil. It is impartial in its dealings with people and groups, but it is not neutral in its value system. Our Constitution certainly does not debar the state from enforcing morality ... The question of commercial sex must ... be looked at not through the lens of certain popular conceptions of morality, but through that of constitutionally articulated values, more particularly those that concern the entitlement of all citizens to live in a state in which gender equality is increasingly made a reality."
\end{abstract}

The court in Jordan upheld the constitutionality of legislation outlawing prostitution in South Africa. The case has been the subject of much scholarly critique, and it is open to question whether or not the court was correct in its finding. The central purpose of this article is not, however, to engage in a detailed critique of the Jordan case. The main focus of this article is to frame the debate from a liberal perspective. From the discussion to this point, it should be clear why the protection of individual freedom is so important to liberal thinkers. It should also be clear that, for a liberal, moral outrage on the part of the majority in society is not a sufficient reason, in and of itself, to unleash the criminal law against a particular practice. What, however, of the real harm that is said to be caused by prostitution, and in particular the harm suffered by the prostitutes themselves? Let us turn now to the manner in which liberal thinkers approach the issue of paternalism and the law. This will involve discussion of an important sub-issue, that is, the "reality" of the consent by prostitutes to engage in this (dangerous?) form of work.

\title{
4 PATERNALISM, PROSTITUTION AND THE LAW
}

We may begin this discussion by examining the views of Herbert Hart. While Hart is in general agreement with the arguments put forward by Mill, he differs significantly with the latter on the question of paternalism, that is, whether or not the law should, in certain instances, be allowed to protect people from themselves. Hart begins by pointing out that "the wane of laissez faire since Mill's day is one of the commonplaces of social history, and instances of paternalism now abound in our law, criminal and civil.,"45 Hart states that certain of Mill's arguments against paternalism, for example his criticism of restrictions on the sale of drugs, "may now appear to us

S v Jordan 20026 SA 642 (CC).

44 Per Justices O'Regan and Sachs in S v Jordan supra par 104 and 105.

45 Hart 32. 
fantastic" ${ }^{46}$ The reason for this, Hart explains, is that the concepts of free choice and consent were understood very differently in Mill's time than they are in the present:

"No doubt if we no longer sympathize with this criticism [i.e. Mill's criticism of restrictions on the sale of drugs] this is due, in part, to a general decline in the belief that individuals know their own interests best, and to an increased awareness of a great range of factors which diminish the significance to be attached to an apparently free choice or to consent. Choices may be made or consent given without adequate reflection or appreciation of the consequences; or in pursuit of merely transitory desires; or in various predicaments when the judgment is likely to be clouded; or under inner psychological compulsion; or under pressure by others of a kind too subtle to be susceptible of proof in a law court."

Clearly, Mill's argument in favour of allowing individuals the freedom to choose or consent to conduct which may be harmful to themselves (as long as it does not harm anyone else), depends upon that choice or consent being truly free. If the choice is not free and/or the consent is not true, as is the case when the individual involved is a child, or is of unsound mind, or is being subjected to obvious external pressure or duress, it seems clear that the law is entitled to intervene to protect the individual from him or herself. A central issue to be decided, therefore, is the extent to which the particular individual involved is truly free to make a decision about the conduct in question. Apart from those cases referred to above in relation to which no one will disagree that law is entitled to intervene - children, persons of unsound mind, persons subject to obvious external pressure or duress etcetera - one's ideological orientation may affect the manner in which one answers this question. The manner in which one conceives of the typical individual and his/her place within the current social, political and economic structure, will influence the extent to which one believes that any particular individual is truly free to choose or consent to specific conduct. Hart points out that Mill's view of the typical individual (or "normal human being" as he puts it) is, perhaps, somewhat outdated:

"Underlying Mill's extreme fear of paternalism there perhaps is a conception of what a normal human being is like which now seems not to correspond to the facts. Mill, in fact, endows him with too much of the psychology of a middleaged man whose desires are relatively fixed, not liable to be artificially stimulated by external influences; who knows what he wants and what gives him satisfaction or happiness; and who pursues these things when he can.

It is certainly a mistake to conceive of the typical individual within society today as a middle-aged, middle-class man, who is fully aware of the consequences of choosing to engage in particular conduct, which he knows may be harmful to himself, but who makes that choice anyway, and whose freedom of choice deserves to be respected. But surely it is also a mistake to conceive of the typical individual as a helpless victim of class/race/gender oppression, pushed hither and thither by social/political/economic forces, whose choices are never free, and who is in constant need of big brother in

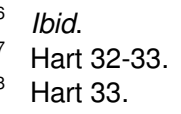


the form of the law to save him/her from him/herself. While Mill may, perhaps, be accused of adopting an extreme liberal view of "the individual", those who might argue that the choices made by workers in a capitalist society are never free due to class oppression, or that the choices made by women in a patriarchal society are never free due to gender oppression, or that the choices made by members of oppressed racial groups are never free due to racial oppression - even if the individuals concerned profess that their choices have been freely made - would seem to be adopting an equally extreme position. Such a position leaves little scope for the freedom of the individual and, perhaps, opens the path to totalitarianism of some sort or another. Hart seems to opt for a middle path. He argues that while a modification of Mill's principles is required in order to accommodate certain instances of paternalism:

"the modified principles would not abandon the objection to the use of the criminal law merely to enforce positive morality. They would only have to provide that harming others is something we may still seek to prevent by use of the criminal law, even when the victims consent to or assist in the acts which are harmful to them."

For Hart, a degree of legal paternalism is acceptable for the reasons given, but what he terms "legal moralism" (that is, in the absence of harm to others, using the law purely to enforce the moral principles of the majority) is not.

The issue of legal paternalism has been extensively analysed by the eminent philosopher, Joel Feinberg, in his work Harm to Self - The Moral Limits of the Criminal Law. ${ }^{50}$ Feinberg distinguishes between "hard" and "soft" paternalism. According to Feinberg, the former type of paternalism "will accept as a reason for criminal legislation that it is necessary to protect competent adults, against their will, from the harmful consequences even of their fully voluntary choices and undertakings. ${ }^{51}$ Clearly, this type of paternalism is not acceptable to liberal thinkers. Liberals are, however, more

49 Ibid.

50 Feinberg Harm to Self - The Moral Limits of the Criminal Law (1986). This is the third of four volumes in which Feinberg assesses which kinds of conduct may be made criminal by a legislature without interfering with the moral autonomy of individual citizens, and which may not. In his seminal four-volume work, Feinberg examines four "liberty-limiting principles" ie, principles that have traditionally been used to justify why the state is entitled to make conduct of a certain kind criminal. The four principles in question are, to use Feinberg's terms: 1. "the harm-to-others principle"; 2 . "the offence principle"; 3. "legal paternalism"; and 4. "legal moralism". See Feinberg ix. These principles maintain that "it is always a good and relevant reason in support of penal legislation that": 1. it is necessary "to prevent harm to persons other than the actor" (the harm-to-others principle); 2. "it is necessary to prevent hurt or offence (as opposed to injury or harm) to others" (the offence principle); 3 . "it is necessary to prevent harm to the very person it prohibits from acting, as opposed to "others"' (legal paternalism); and 4. "it is necessary to prevent inherently immoral conduct whether or not such conduct is harmful or offensive to anyone" (legal moralism). See Feinberg ix. Feinberg defines "liberalism" as "the view that the harm and offence principles, duly clarified and qualified, between them exhaust the class of morally relevant reasons for criminal prohibitions." See Feinberg x. In other words, according to this view, if one is truly committed to the principles of "liberalism", then one should be committed to the position that neither legal paternalism nor legal paternalism is a good enough reason for the criminal law to ban certain conduct.

51 Feinberg 12. 
likely to approve of "soft paternalism", which Feinberg describes as follows: "Soft paternalism holds that the state has the right to prevent self-regarding harmful conduct ... when but only when that conduct is substantially nonvoluntary, or when temporary intervention is necessary to establish whether it is voluntary or not. ${ }^{, 52}$ In other words, soft paternalism allows the law to protect people from their own "non-voluntary" choices. ${ }^{53}$ Feinberg puts is as follows:

"[S]oft paternalism would permit $B$ to agree to an arrangement with $A$ that is dangerous or harmful to $B^{\prime}$ s interests, if but only if $B$ 's consent to it is voluntary. To the extent that $B$ 's consent is not fully voluntary, the law is justified in intervening "for his sake."”

The crucial question, of course, is the manner in which we determine whether a choice made by a person, or the consent given by him or her, is voluntary or non-voluntary. In other words, how do we determine whether or not the choice made is truly his/her choice, or whether or not his/her consent amounts to a "real consent"?

In analysing the difficult notion of "voluntary choice", Feinberg suggests that we should "think of voluntariness as a matter of degree" and explains as follows:

"At one end of a spectrum are the acts and choices that Aristotle called 'deliberately chosen', and which I shall call for the moment (departing from Aristotle) perfectly voluntary. Only the actions of normal adult human beings in full control of their deliberative faculties can qualify for that description. Such persons assume a risk in a perfectly voluntary way if they shoulder it when fully informed of all relevant facts and contingencies, with their eyes wide open, so to speak, and in the absence of all coercive pressure. In the ideal case, there must be calmness and deliberateness ..., no distracting or unsettling emotions, no neurotic compulsion, no misunderstanding ... At the very opposite end of the

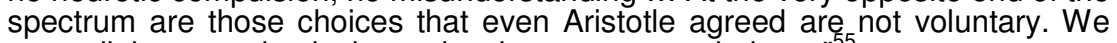
can call these, and only these, involuntary acts or choices.

Feinberg points out that most choices made by people in the real world are neither "perfectly voluntary" nor completely "involuntary", but fall somewhere between these two extremes. He concludes that "we may formulate relatively strict (high) standards of voluntariness or relatively low standards of voluntariness in deciding, in a given context and for a given purpose, whether a dangerous choice is voluntary enough to be immune from interference." 56 In other words, he seems to be suggesting a shifting standard for voluntariness, which is context dependent. Even though a particular choice may not be "perfectly voluntary" (in the sense explained above), the important question becomes whether or not it is "voluntary enough" within the particular context in which the choice is made, to make it off-limits to interference by paternalistic law-makers.

52 Ibid.

53 If their choices are "non-voluntary", however, can the law in such situations really be said to be acting "paternalistically"? Feinberg in fact comments that it is uncertain "that "soft paternalism' is 'paternalistic' at all, in any clear sense". See Feinberg 12.

54 Feinberg 12.

55 Feinberg 104.

56 Feinberg 104-105. 
It is not possible in an article such as this to delve any more deeply into the nuances of this highly complex debate. Where does the above discussion leave us, however, in relation to the issue of central concern in the present article? How are we to assess the "choices" made by South African sex workers to engage in this line of work, as well as the "choices" of their clients to make use of their services? Are the choices of sex workers constrained to such an extent by a harsh patriarchal and capitalist system, so as to render them sufficiently "non-voluntary" in Feinberg's terms, to justify intervention by the criminal law in accordance with the principles of "soft paternalism"? Or are we able to conclude that the "choices" of sex workers and their clients in South Africa today are "voluntary enough", so as to raise the suspicion that the present South African legal position in relation to prostitution is, at best, a form of "hard paternalism", which cannot be condoned by true liberal thinkers? The answers to these questions no doubt lie in the realm of empirical research which, once again, is beyond the scope of this short article. It may be worth ending this section, however, by making reference to one fairly recent empirical study, which did reach certain conclusions on the issue of the choices made by sex workers in South Africa. After a two-year study by the Institute of Security Studies (ISS) and the Sex Worker Education and Advocacy Taskforce (SWEAT) of the sexwork industry in Cape Town, researchers Chandré Gould and Nicolé Fick concluded, inter alia, as follows:

"Our evidence suggests that while sex workers are often subject to exploitative or abusive working conditions, very few are forced to sell sex. Very few are tricked into selling sex in the first place, and most take up the work because it is a rational choice given its earning potential. Like Steinfatt's study of the Cambodian sex industry (2002) we found that the number of women who are debt-bonded or trafficked was much lower than suggested by previous studies ... We are not suggesting that there are no victims of trafficking in Cape Town, nor that victims of trafficking might not be found elsewhere in South Africa. But we can conclude that trafficking is not a major feature of the sex-work industry in Cape Town. What we did find is that exploitation and abuse of women working in the industry is not uncommon."

The primary recommendation of the above study was that the sex-work industry in South Africa be decriminalized and regulated:

"It is our considered view, supported by international research, that the factors that drive exploitation and abuse are the unregulated nature of the sex work industry, the plentiful supply of exploitable labour, and the differential power relations between brothel owners and sex workers, and between clients and

57 Chandré Gould in collaboration with Nicolé Fick (SWEAT) Selling Sex in Cape Town - Sex Work and Trafficking in a South African City (2008) Chapter Ten - Conclusion 154. In elaboration of this general point, it is interesting to note that, of the Conclusion 156, the authors state further as follows: "We found that most sex workers make decisions based on their need for survival and follow those decisions through, even when it means that they have to do work that they may dislike. Most who work in the sex industry do so out of financial necessity (whether for survival or to maintain a more middle-class lifestyle). We found that in most cases, they were able to extract themselves from situations they wanted to move out of ... On the other hand, we also found that exploitation and abuse are common in the sex work industry. This has to be understood in the context of the power relations between those in the industry. It would be naïve to ignore the power imbalances between sex workers and clients, sex workers and state authorities, sex workers and brothel owners, and the fact that sex workers have very little recourse to the law." 
PROPOSED LEGALISATION OF PROSTITUTION IN SOUTH AFRICA 555

sex workers ... Our primary recommendation therefore is to decriminalize and regulate the sex-work industry. We urge the government to remove all the laws that make the sale of sex by consenting adults a crime."

\section{CONCLUSION}

Those standing outside the liberal tradition may be justly critical of the liberal fixation on issues of individual freedom, while failing to accord sufficient weight to issues of class, gender and racial oppression. In the African context in particular, with its history of colonialism and racist exploitation, there is a need, perhaps, to be cautious in making too much of the virtues of individuality and non-conformity. In his book "No Future Without Forgiveness", Desmond Tutu submits that, within traditional African thought, a very high value is ascribed to social harmony as a basic good:

"Harmony, friendliness, community are great goods. Social harmony is for us the summum bonum - the greatest good. Anything that subverts or undermines this sought-after good is to be avoided like the plague. Anger, resentment, lust for revenge, even success through aggressive competitiveness, are corrosive of this good.

Although individuality and non-conformity need not necessarily be destructive of social harmony, championing the former values within an African context as opposed to an Anglo-American context, for example, might prove more of a "hard sell" in the case of the former as opposed to the latter. Nevertheless, it is submitted that, particularly in a multicultural African country such as South Africa, the values of individuality and non-conformity, as championed by John Stuart Mill, Herbert Hart, Joel Feinberg, and others, remain vitally important. ${ }^{60}$

While not resolving the debate as to whether or not prostitution ought to be legalized in South Africa, this article has attempted, at least, to frame the debate from a liberal perspective. The liberal values that underpin South Africa's constitutional democracy run deep, which means that liberal concerns around issues of individual freedom, as they relate to this debate, cannot easily be dismissed. In order to convince those committed to truly liberal principles (in Joel Feinberg's terms) of the need for the criminal law to prohibit sex work, it must be shown that it causes either "harm" or "offence" (in the sense that each of these terms are employed by Feinberg) to others. This article has discussed neither of these principles in detail. Neither has it attempted to discuss or decide upon whether or not sex work causes "harm" or "offence" to others. What has been discussed are the principles of "legal moralism" and "legal paternalism". It is hoped that the reasons why liberals will accept neither of these principles as a legitimate reason to criminalize sex work have been adequately explained.

58 Gould in collaboration with Fick (SWEAT) Chapter Ten - Conclusion 159.

59 Desmond Tutu No Future Without Forgiveness (1999) 35.

60 See Louw "Ubuntu and the Challenges of Multiculturalism in Post-apartheid South Africa" 200115 Quest 15-36. 